\title{
MODERNISMO, FUTURISMO E POLÊMICAS LITERÁRIAS NA REVISTA CARETA (1909-1922)
}

\section{Joachin de Melo Azevedo Sobrinho Neto'}

Fillipo Marinetti (1876-1944), escritor italiano, publicou seu "Manifesto futurista" dividido em onze tópicos - originalmente, em francês, no jornal Le Figaro, em 1909. O escritor teceu, em tons panfletários, uma apologética da velocidade, da eletricidade, da força bruta, além de um fervoroso elogio da guerra, "única higiene do mundo", além do "militarismo" e "patriotismo" trecho que trata, especificamente, da guerra e pode ser interpretado enquanto uma amostra das tensões que caracterizaram os prelúdios da I Guerra Mundial, quando as elites políticas e militares de várias potências econômicas e imperiais da Europa acreditavam, realmente, que a violência $e$ a agressividade postas em prática eram a melhor forma de resolver disputas internacionais ou tensões sociais locais. Por fim, busca convencer os leitores da beleza que existe nas paisagens urbanas cerradas de edifícios, em avenidas iluminadas artificialmente, cidades cobertas pela fumaça das fábricas e na interface entre o homem e a tecnologia, simbolizada pela imagem do motorista que ao pilotar o automóvel estava exercendo pleno domínio sobre a velocidade e o progresso.

O futurismo portanto, enquanto vanguarda estética, está estreitamente entrelaçado com o conceito de modernismo. Segundo os críticos literários McFarlane e Bradbury, ao prefaciarem a obra Modernismo: guia geral (1890-1930), o modernismo enquanto movimento literário foi bastante expressivo e abarcou manifestações políticas, teorias e grupos sociais, ocorrendo em diferentes lugares e momentos. Alguns manifestos presentes nessa fase eram feitos através de redes de intelectuais, que tinham em comum o gosto pela discussão de teorias e correntes estéticas, passando de um país a outro e também por meio de pequenos grupos ativistas. Modernismo e futurismo representam, no começo do século XX, um novo olhar para a arte, bem como suas funções ${ }^{3}$.

$\mathrm{Na}$ mesma obra, Judy Rawson ${ }^{4}$ esclarece que não dá para atribuir todos os créditos em relação a difusão do futurismo italiano para a figura de Marinetti. Existiram vários personagens que influenciaram esse Manifesto, como, por exemplo, o veterano de guerra e político Mussolini, que estreitou muito a relação entre futurismo e fascismo. No entanto, o Manifesto não recebeu apoio total entre os intelectuais italianos. Os aeroplanos e carros que representavam, para Marinetti e para o movimento futurista, os maiores símbolos do progresso da época e o triunfo da

\footnotetext{
${ }^{1}$ Doutor em História pela Universidade Federal de Santa Catarina. Professor Adjunto da Faculdade de Formação de Professores da Universidade de Pernambuco, Campus de Petrolina. E-Mail: <joaquimmelo@msn.com>.

${ }^{2}$ MARINNETTI, Filippo. "Manifeste du Futurisme". Le Figaro, Paris, fev. 1909, p. 1.

${ }^{3}$ Cf. BRADBURY, Malcolm \& McFARLANE, James (orgs.). Modernismo: guia geral (1890-1930). Tradução de Denise Bottmann. São Paulo: Companhia das Letras, 1989, p. 19.

${ }^{4}$ RAWSON, Judy. "O futurismo italiano". In: BRADBURY \& McFARLANE, Modernismo..., p. 198-210.
} 
racionalidade humana sobre as limitações impostas pela natureza também foram satirizados em imagens, prosa e verso por dissidentes. No entanto, para os futuristas, esses dispositivos modernos ilustravam o avanço que a técnica humana alcançou. Em outros termos, essa imensa admiração futurista pela indústria automobilística teve todo um caráter etnocêntrico.

Para Raymond Williams, em Política do modernismo: contra os novos conformistas, essa tendência artística abarca várias correntes ou movimentos culturais que arregimentaram novas propostas para a literatura $e$ as artes visuais. Sendo assim, modernismo e futurismo, fenômenos geminados, podem ser conceituados enquanto movimentos pertencentes a história contemporânea da arte. As duas correntes de ideias e expressões imagéticas passaram a reivindicar o status de representantes de uma época que já estava delineada a partir do ritmo e compasso da indústria em larga escala, pelo uso da tecnologia em diversas instâncias do cotidiano e por uma concepção de tempo utilitarista e enaltecedora da pressa. Na primeira década do século $\mathrm{XX}$, todos os campos da arte sentiram o abalo provocado pelos ditames da tecnocracia moderna.

Muitos manifestos e expressões artísticas de correntes vanguardistas, consolidadas pelo modernismo, continuam despertando interesse e curiosidades públicas na atualidade. Conforme salienta o autor, o modernismo também ganha projeção, no mundo ocidental, a partir de uma determinada atmosfera artística favorável para polêmicas e competições estéticas: "os poetas simbolistas da década de 1880 são considerados superados pelos imagistas, surrealistas, futuristas, formalistas e outros grupos a partir de 1910"

As obras mais significativas dessa época foram engendradas por autores que buscaram decantar, em prosa, verso e imagens, os significados políticos, espirituais e morfológicos da modernidade. Daí a matriz de pensamento que vai estimular o repúdio vanguardista pelas tradições culturais burguesas estabelecidas pelas academias:

O modernismo definido dessa forma divide-se politicamente e não apenas entre movimentos específicos, mas também dentro deles. Mantendo-se antiburgueses, seus representantes ou escolhem a valorização aristocrática anterior da arte como um domínio sagrado acima do dinheiro e do comércio, ou as doutrinas revolucionárias, proclamadas desde 1848, da arte como uma vanguarda libertadora da consciência popular. ${ }^{6}$

Vale salientar, portanto, que durante o primeiro decênio do século $\mathrm{XX}$, os movimentos vanguardistas conquistaram espaços institucionais importantes $e$ visibilidade diante da opinião pública em diferentes localidades. Não havia uma unidade política entre futuristas, imagistas, cubistas ou formalistas, porém o culto desdenhoso pelo novo era quase unânime. A orientação geral era inovar a qualquer

\footnotetext{
${ }^{5}$ WILLIAMS, Raymond. Política do Modernismo: contra novos conformistas. Tradução de André Glaser. São Paulo: Editora Unesp, 2011, p. 3.

${ }^{6}$ WILLIAMS, Política do Modernismo..., p. 5-6.
} 
custo, inclusive de forma herética. $\mathrm{O}$ que gerou toda sorte de fragmentações entre a intelectualidade que deu corpus para as ideias modernistas. Esse fato explica o porquê de muitos dos defensores do vanguardismo e da marginalidade artística acabarem ocupando cátedras nas universidades que tanto diziam desprezar. O modernismo, ainda conforme esclarecimentos de Williams, em pouco tempo, vai perder o seu caráter antiburguês e ser integrado a lógica global do capitalismo: suas manifestações tornaram-se, gradualmente, produtos de consumo dentro de um panorama de competição cultural e interação comercial entre diferentes países.

Em um criterioso estudo sobre a consolidação do modernismo entre os intelectuais do Rio de Janeiro, nas três primeiras décadas do século XX, Ângela de Castro Gomes esclarece que as ideias futuristas de Marinetti não eram desconhecidas pelos intelectuais que movimentaram a imprensa durante a Primeira República. Muitas de suas propostas já estabeleciam ressonâncias em impressos como a FonFon, O Malho, Festa, Terra de Sol e outras mais mantidas por grupos diversos que disputavam reconhecimento público em meio a acaloradas polêmicas ${ }^{7}$. Sendo assim, elencamos a revista de variedades Careta, que circulou no Rio de Janeiro de 1908 a 1960, enquanto fonte primária para debater as repercussóes do futurismo entre os intelectuais que atuaram na imprensa carioca e em um contexto anterior a Semana de Arte Moderna. A Careta Reuniu jornalistas de diferentes matizes, desde polemistas, tais quais Bastos Tigre (1882-1957) e Lima Barreto (1881-1922), até acadêmicos do porte de Martins Fontes (1884-1937) e Olavo Bilac (1865-1918). Agremiou também entre seu corpo editorial, alguns dos mais talentosos cartunistas da Primeira República, como J. Carlos (1884-1950). Trata-se, portanto, de uma fonte que pode fornecer valiosas informações sobre cosmopolitismo e cultura impressa brasileira nos primeiros decênios do século XX.

Um dos primeiros registros encontrados na Careta acerca do futurismo é o texto "A poesia futurista e sua introdução e seu progresso no Brazil: ensaio crítico", publicado na edição de 14 de junho de 1913 e assinado por D. Xiquote. O uso de pseudônimos por parte de escritores na Primeira República era um recurso comum e possuía várias finalidades. Dentre as quais podemos destacar: ocultar a identidade real do autor para que as polêmicas em relação a temas ou outros literatos fossem as mais ferinas possíveis, bem como a incorporação de alter ego que possibilitava, na maioria das vezes, que o literato assumisse posicionamentos políticos ou estéticos dos quais discordava ou tinha receios de os externar publicamente. No citado ensaio, D. Xiquote fala acerca de um sugestivo triunfo que a poesia futurista representava em relação a literatura dos decadentistas, românticos e parnasianos.

Falarei do 'Futurismo' a nova escola triunfante que vem decidida a derrocar as catedrais românticas $e$ as turris eburneas dos Parnasianos.

Ela veio - para empregar uma expressão de futuro na língua

- de chapéu de sol aberto. Chegou, viu e venceu, como o

${ }^{7}$ Cf. GOMES, Ângela de Castro. Essa gente do Rio...: modernismo e nacionalismo. Rio de Janeiro: FGV, 1999. 
autor da Condessa Herminia, uma obra inconscientemente futurista, por sinal.

Entre nós o novo credo poético tem até agora poucos cultores mas de qualidade a suprir o número. A sua obra conserva-se inédita, o que lhe dá ainda maior valor; aliás, sendo obra para o futuro, ficaria deslocada no mesmo presente, como ficaram Código Civil e o monumento de Floriano.

Entretanto, graças à gentileza de um futurista indiscreto, conseguimos devassar alguns chefes de obra (não confundir com empreiteiros) de vates indígenas, que, tendo se dedicado ao Futurismo, aguardam, pacientes o veredictum da posteridade. ${ }^{8}$

$\mathrm{O}$ autor escolhe trechos de quatro poemas atribuídos as alcunhas de Solferino D'Albuquerque, Floriano de Lemos, Figueiredo Pimentel e Domingos Mangarinos enquanto amostras relevantes da poesia futurista nacional. Detalhar o teor desses escritos e elucidar sua correlação com as diretrizes da estética futurista foge ao escopo deste artigo. No entanto, interessa aqui tecer algumas considerações sobre o autor do citado texto. D. Xiquote foi o pseudônimo adotado pelo pernambucano Bastos Tigre, desde 1902, quando estreou na república das letras carioca atuando no semanário estudantil Tagarela: um folheto humorístico mantido pelos discentes do Curso de Engenharia da Escola Politécnica.

Marcelo Balaban, ao elaborar um relevante estudo acerca da biografia intelectual do autor, sugere que, ao assinar os primeiros versos fazendo um trocadilho com o nome do principal personagem de Cervantes, Bastos Tigre tanto estava afirmando sua inclinação para a verve humorística, bem como reivindicando o lugar de homem de letras militante; reformador da sociedade: uma tendência que acompanhou quase toda a geração de escritores da chamada Belle Époque.

Em 1913, colaborando com A Careta e o bem conceituado Jornal do Commercio, Tigre demonstra não só o aumento da sua bagagem de leituras, passando da composição de sonetos para o terreno da crítica literária, mas também que já estava colhendo os frutos de seu desempenho literário. Sendo convidado para proferir conferências em um contexto no qual os jornalistas, "artífices da palavra, profissionais das letras [...], consolidavam um sentido para a sua atuação" ${ }^{9}$. Nesses termos, esses atores sociais se valiam de polêmicas e palestras enquanto ferramentas bastante úteis para a "consolidação de seu prestígio"10.

O texto de Bastos Tigre, embora ainda marcado por um estilo rebuscado de escrita, pode ser interpretado enquanto um sintoma das tensões estéticas que movimentaram algumas das principais polêmicas literárias registradas pelo mercado editorial da Primeira República. Provocar os parnasianos e usar a temática da

${ }^{8}$ D. XIQUOTE (Bastos Tigre). "A poesia futurista e sua introdução e seu progresso no Brazil: ensaio crítico". Careta, Rio de Janeiro, ano VI, n. 263, jun. 1913, p. 10.

${ }^{9}$ BALABAN, Marcelo. Musa travessa: Bastos Tigre e a literatura da Belle Époque carioca. Dissertação (Mestrado em História). Pontifícia Universidade Católica do Rio de Janeiro. Rio de Janeiro, 2000, p. 95.

${ }^{10}$ BALABAN, Musa travessa..., p. 95. 
chegada da poesia futurista no Brasil era uma maneira de Tigre mostrar-se antenado com as últimas tendências das vanguardas europeias. No entanto, podemos deduzir que, no artigo, a postura crítica do autor em relação aos parnasianos acaba resvalando em um tom excessivamente apologético do futurismo que não era, necessariamente, um consenso entre os intelectuais que escreviam para a Careta.

No artigo anônimo intitulado "Cubistas e cubismo", publicado na edição da Careta de 24 de janeiro de 1914, cujo autor menciona que tempos atrás houve uma exposição de pintura no Salão dos Novos em Paris consagrada à uma nova escola artística. O artigo está ilustrado por fotografias das esculturas Senhorita, A cópia e Retrato de homem do espanhol Augusto Aguero e reproduções dos quadros Natureza morta, Retrato e Cabeça de jovem de seu compatriota Juan Gris. A retórica do misterioso crítico de arte é marcada pelo deboche, atribuindo para a técnica de composição cubista o seguinte método:

Um bando de rapazes e raparigas que se divertiam [...] fizeram vir um jumento; amarraram-no a um esteio; puseramlhe bem amarrada a cauda uma brocha, por trás do burro uma tela alva e virginal. Mergulharam a brocha em uma lata de tinta e começaram a passar sobre o lombo do quadrúpede, fazendo-lhe cócegas, varinhas carregadas de folhagem.

Atribuindo as cócegas às moscas, o pacífico animalejo tratou de enxotá-las com a cauda, e a cada movimento a brocha passando pela tela deixava um traço; mudando de quando em quando a tinta no fim de algum tempo toda a tela desaparecia sob a tinta acumulada e estava o quadro completo.

[...]

Marinetti deita o seu manifesto declarando guerra a tudo quanto se fez até hoje, afirmando as bases erradas em que se assentam as nossas convicções.

Os discípulos vendo que o aprendizado era fácil, pois que quanto mais extravagante fosse a execução mais se aproximava o autor das ideias dos grãos-lamas do futurismo surgiram em massa, e Paris se deleita todos os anos vendo os horrores dos cubistas. ${ }^{11}$

É bastante provável que o emissor destas opiniões, enquanto crítico de arte, estava vinculado com as tendências parnasianas brasileiras, marcadas pelo apreço pela linguagem floreada e repleta de jargóes greco-latinos, além do deslumbre pelo realismo e naturalismo iconográfico. Embora pareça bem humorada, essa caricatura do cubismo e a sua correlação com o futurismo é simplista. Mercè Vidal, especialista em história da arte, esclarece que a escultura cubista de Argero estava comprometida com a diluição das fronteiras entre estatuária e pintura. Definindo o cubismo enquanto exercícios espirituais da arte contemporânea, Vidal atenta com pertinência

11 “CUBISTAS e Cubismo". Careta, Rio de Janeiro, ano VII, n. 295, jan. 1914. 
para a influência que as artes plásticas africanas exerceram sobre Aguero em sua busca por um estilo que aproximasse a arte de um ideal rústico e fosse capaz de causar uma ruptura com a perfeição dos corpos representados pelo classicismo ${ }^{12}$. Nestes termos, embora a transgressão estética fosse a ordem do dia, entre os vanguardistas, essa importante confluência entre cubismo e cultura africana esbarra nas convicções eurocêntricas de Marinetti. O nivelamento, portanto, entre cubismo e futurismo feito pelo beletrista brasileiro foi bastante enviesado.

Jean Grimace também expressou seu entusiasmo com as ideias futuristas nas páginas da Careta, na edição datada de 02 de maio de 1914, por meio do poema "Celebridade itinerante". Este pseudônimo é particularmente interessante porque trata-se de uma junção entre um primeiro nome francês comum e um vocábulo também de origem francófona usado para definir expressões faciais caricatas. Tanto serve como indício do fascínio que a cultura francesa exerceu entre grande parte dos jornalistas brasileiros do começo do século XX, bem como do compromisso pessoal do autor em face da proposta editorial do periódico para o qual colaborava. Desse modo, o poema está assim publicado nas páginas da revista:

Tangem-se os sinos já pela chegada

Do chefe, que aí vem, do futurismo,

Inventivo, assombroso camarada,

Cujo talento é um verdadeiro abismo.

Ele vem de Paris e, assim, mais nada

Seria do que estupido snobismo

Negar-lhe a gente aqui tão atrasada

O gênio transportado ao paroxismo.

Organizem-se, pois, festas brilhantes, A que não faltem matinées dansantes, Pão de Açucar, Tijuca e Corcovado.

Si lhe não dermos cousa nunca vista, Importante como é, o futurista

Sem mais aquela partirá passado. ${ }^{13}$

Na verdade, o modernismo francês - corrente estética bem difundida entre artistas de diferentes recantos do Ocidente - em sua vertente finissecular, foi bem mais responsável pelo entrecruzamento entre consciência moderna $e$ as tendências decadentistas da iconografia e prosa do que por uma suposta irradiação do futurismo. Conforme apontam as reflexões de especialistas na temática, na já citada obra

\footnotetext{
${ }^{12}$ Cf. VIDAL, Mercè. 1912: L'Exposió d'Art Cubista de Les Galeries Dalmau. Barcelona: Gráficas Rey, 1996.

${ }^{13}$ GRIMACE, Jean (Edigar Barbosa de Barros). "Celebridade Itinerante". Careta, Rio de Janeiro, ano VII, n. 306, mai. 1914, p. 44.
} 
organizada por Bradbury e MacFarlane ${ }^{14}$, Itália e Rússia foram as principais referências mundiais em termos do futurismo e seus desdobramentos estéticos, políticos e técnicos. Apesar de ter sido veiculado nas páginas do Le Figaro, o manifesto de Marinetti estava imerso em duras críticas ao modernismo em sua versão fin-de-siécle. Porém, a apoteose do futurismo realizada por Jean Grimace possui fortes implicações biográficas.

Jean Grimace era o pseudônimo de Edigar Barbosa de Barros: médico, escritor, poeta, tradutor, teatrólogo e subdiretor dos telégrafos do Distrito Federal. Também escreveu na Careta sob as alcunhas de João Rialto e Alfio Castelo ${ }^{15}$. Neste caso, por ter sido também autor de várias traduções e de manuais voltados para o funcionamento e operação de sistemas de comunicação por telégrafos, é bastante provável que a adesão aos imperativos do futurismo por parte de Edgar Barbosa ${ }^{16}$, que aparece decantada nos versos de seu alter ego Jean Grimace, tenha sido motivada pelo importante papel que esse ator histórico desempenhou ao longo do remodelamento e modernização do Rio de Janeiro na Primeira República.

Nestes termos, o livro A tropical Belle Époque, do historiador Jeffrey Needell, continua sendo uma referência fundamental para se entender a obsessão das elites intelectuais, que habitaram o Rio de Janeiro na Primeira República, pela cultura europeia. Foi uma tendência, partilhada entre toda uma geração de letrados brasileiros, demonstrar sintonia com a aparência aristocrática mantida pela burguesia francesa e inglesa, bem como de outras partes do mundo europeu, descritas ou fotografadas em diversos periódicos cariocas. Adotar a moda europeia, buscar demonstrar algum tipo de afinidade com as polêmicas literárias que circulavam no Velho Mundo, os estudos, culinária e etiquetas nas relações sociais era uma forma simbólica de demonstrar civilidade dentro do paradigma eurocêntrico deste conceito.

Ainda de acordo com Needell, a seara de escritores na qual podemos incluir Edigar Barbosa, buscou ocupar cargos públicos de prestígio, seguir carreira diplomática ou exercer ofícios liberais e considerados "respeitáveis" pela sociedade republicana: profissões que abarcavam os trabalhos de professor, jornalista, médico, engenheiro, advogado. Sendo assim, a edificação de prédios em estilo Art Noveau ou a construção da Avenida Central são iniciativas que precisam ser compreendidas em

\footnotetext{
${ }^{14}$ BRADBURY \& McFARLANE, Modernismo...

${ }^{15}$ Informação constatada na Tese de Doutorado em História Social, intitulada Caricaturas carnavalescas: Carnaval e humor no Rio de Janeiro através das revistas ilustradas Fon Fon! e Careta (1908-1921), de Fabiana Lopes da Cunha. Ao analisar fontes iconográficas e textuais nas duas principais revistas de variedades da então capital republicana, Fabiana L. Cunha problematizou as representações $e$ opiniões acerca do carnaval realizadas por uma série de ilustradores e jornalistas: alguns dos quais a identidade permanece um mistério até hoje, devido ao uso dos pseudônimos. A intenção da autora foi elaborar análises que entrecruzam a temática do carnaval - conforme retratada na Fon Fon! e Careta com o cotidiano, humor, política, sociedade e atividades intelectuais na Primeira República. Sendo assim, os apelidos usados por Edgar Barbosa de Ramos aparecem revelados para o leitor no terceiro capítulo da mencionada Tese. Cf. CUNHA, Fabiana Lopes da. Caricaturas carnavalescas: Carnaval e humor no Rio de Janeiro através das revistas ilustradas Fon Fon! e Careta (1908-1921). Tese (Doutorado em História Social). Universidade de São Paulo. São Paulo, 2008, p. 198-277.

${ }^{16}$ Dentre as obras atribuídas a Edigar B. Barros, encontramos Memórias históricas dos Telégrafos no Brasil (1908); Convenção telegráfica internacional e respectivo regulamento (1908); Guia Telegráfico (1911); Manual de contabilidade para uso da R. G. dos Telégrafos (1923), dentre outros.
} 
um contexto cultural mais amplo. As elites dirigentes do Rio desejavam que a então capital da República tanto servisse de vitrine para o restante do país, bem como fosse bem vista internacionalmente. As leituras e debates sobre as vertentes estéticas europeias são indicativos também desse verdadeiro fetiche, tão bem investigado pelo autor e nutridos por vários intelectuais, em esconder o Brasil miscigenado e das grandes disparidades sociais e insistir em uma pretensa proximidade com a longínqua realidade francesa ${ }^{17}$.

Nesse mesmo diapasão, Flora Süssekind postula que, a partir da segunda metade do século XIX, inovações técnicas estrangeiras consideradas avançadas para a época foram implantadas em vários setores mercadológicos do país e causaram um profundo impacto na impressa brasileira. Os novos dispositivos mecânicos, de conforto, lazer ou comunicação que aportavam na capital federal foram motivo de amplas especulações na opinião pública e contribuíram para a transformação da sensibilidade dos produtores culturais mais atuantes do Brasil. Em Cinematógrafo das letras: literatura, técnica e modernização no Brasil, a autora sugere que a modernização urbana e técnica do Rio de Janeiro causou transformações também no campo das composições literárias. Houve, portanto, intercâmbios temáticos $e$ materiais entre cultura escrita e artefatos tidos enquanto símbolos do moderno.

As concepções de modernidade e futuro nas fontes analisadas por Süssekind remetem a certa contradição. Vários escritores brasileiros enxergaram na maquinaria das gráficas, locomotivas ou dos aparelhos de mídia e elétricos não ícones do progresso, mas da perturbação dos sentidos. É o caso de Godofredo Rangel (18841951), que no romance Vida ociosa, de 1917, em determinada passagem do enredo,

Elogia no velho gramofone não [...] a sua capacidade de reprodução mecânica de sons previamente gravados; [...] ao contrário, em meio ao seu desgoverno, uma certa proximidade da natureza, dos ruídos de trovões e tempestade e dos acentos animais. ${ }^{18}$

Em outros termos, o que impressionava na máquina não era seu desempenho técnico e sim o que fugia do mundo da técnica. Posicionamento antagônico de um jornalista como Paulo Barreto (1881-1921), o João do Rio, por exemplo, que atribuiu aos novos meios tipográficos, marcados pela capacidade de impressão de jornais, folhetos e livros em larga escala, uma série de características sedutoras. Em texto publicado na antologia Vida vertiginosa, em 1911, o cronista chega a descrever um tipo de utopia futurista na qual o cotidiano na cidade do Rio de Janeiro está repleto de trens subterrâneos, aeroplanos, despertadores elétricos e até mesmo um jornal falante que transmite notícias em milhares de domicílios.

Portanto, pode-se perceber que, de acordo com as relevantes considerações de Flora Süssekind, a imprensa brasileira conseguiu modernizar-se de forma rápida.

${ }^{17}$ Cf. NEEDELL, Jeffrey. A tropical Belle Époque: elite culture and society in turn-of-the-century Rio de Janeiro. Nova York: Cambridge University Press, 1987, p. 178-233.

${ }^{18}$ SÜSSEKIND, Flora. Cinematógrafo das letras: literatura, técnica e modernização no Brasil. São Paulo: Companhia das Letras, 1987, p. 18. 
Havia quem mantivesse resistência ou concordava com esse processo. Porém, mesmo com as críticas, o jornalismo no Brasil, gradualmente, alcançou a modernização esperada por uma parcela de literatos e leitores. O fato é que na esteira da difusão $e$ divulgação de novos dispositivos modernos na Europa, voltados para a comunicação, tivemos uma paulatina substituição do traçado manual pela tipografia mecânica em território nacional e esse processo foi decantado em prosa e verso por intelectuais das mais diversas tendências.

Nesse primeiro momento, da história das ideias futuristas dentro de um contexto nacional, as opiniões emitidas sobre essa corrente política e estética, na Careta, oscilaram bastante entre a apologética ou veemente rejeição dos seus fundamentos. Sobre o pseudônimo de P., outro colunista do periódico carioca, na edição de 16 de maio de 1914, fornece mais elementos para a constatação desta assertiva. Em "Um prédio futurista", o autor afirma que o futurismo estava se alastrando para as Belas Artes. Indício desta tendência, além de exemplos na pintura e escultura, era a arquitetura futurista representada, para P., por meio de uma casa construída no distrito de Chester nos Estados Unidos. A matéria traz quatro fotografias da mencionada habitação, que evidenciam paredes, colunas e muros incrustrados de "velhos canos de esgoto, pedras de calçamento, garrafas vazias, botijas de barro, cacos de louça, garrafões vazios, e toda espécie de material, novo e velho, que o proprietario pode encontrar" ${ }^{19}$. Assim sendo, de acordo com as consideraçóes do anônimo redator:

O dono desse prédio está muito orgulhoso da sua criação $e$ acolhe muito lisonjeado os visitantes, na verdade muito numerosos que vão examiná-lo. Apesar desse sucesso, porém, acreditamos que a arquitetura futurista é de muito pouco futuro. ${ }^{20}$

O tom cético e jocoso que reveste o teor desta reportagem mantém certa sintonia com o texto anteriormente citado sobre arte cubista. Terão sido polêmicas lançadas por um único autor? Ater-se ao desvendamento desta problemática implicaria em um caminho investigativo bastante nebuloso para percorremos. Na verdade, essa preocupação com um rumo supostamente negativo que as belas artes poderiam tomar com o advento do futurismo delimita fronteiras com posturas intelectuais entusiastas do fluxo cultural estrangeiro, principalmente no tocante aos cultos do progresso material e utilitarismo. Em Literatura como missão: tensões sociais e criação cultural na Primeira República, Nicolau Sevcenko sugere que muitos dos testemunhos deixados por críticos culturais, na imprensa carioca, fornecem indícios de consciências que interpretaram a efervescência de ideários estéticos e políticos modernistas enquanto sintomas de decadência moral e espiritual.

De acordo com o autor,

\footnotetext{
${ }^{19}$ P. "Um prédio futurista". Careta, Rio de Janeiro, ano VII, n. 308, mai. 1914, p. 25.

${ }^{20}$ P., "Um prédio futurista", p. 25.
} 
Todos os alicerces da sensibilidade romântica tradicional são rapidamente corroídos até a completa dissolução. Os cronistas acompanham desolados os seus estertores, pranteando-os um a um. Abundam as exprobrações contra a 'tecnologia e a ciência', a 'mecanização e a metodização' da vida moderna, que mataram os ideais do Amor, da Arte e do Sentimento. ${ }^{21}$

Vale salientar que essa sensação de aniquilação das idealizações finisseculares está relacionada com um tipo de desencanto muito próprio da bela época e nutrido entre setores da intelligentsia brasileira que encararam as mudanças institucionais $e$ comportamentais engendradas pela modernização dos trópicos enquanto superficiais $e$ angustiantes. A articulação de núcleos feministas nas principais capitais do país, por exemplo, visava contestar os arquétipos do comportamento das mulheres impostos pelas convenções masculinas burguesas. Vale salientar que movimentos vanguardistas dessa envergadura nem sempre eram tidos como sinônimo de progresso ou vistos como positivos por parcelas significativas dos escritores que desenvolviam atividades jornalísticas no período aqui analisado. Daí o cronista João da Cidade, em 1919, ao escrever sobre as chamadas melindrosas cariocas - mulheres oriundas de determinadas camadas sociais abastadas, que aboliram o uso dos espartilhos, cortavam os cabelos a moda Chanel, optaram pelo uso de vestimentas mais curtas $e$ apreciavam jazz - afirmar que "as criaturinhas que enchem de graça nosso set souberam decifrar o enigma do encantamento. [...] O futurismo do vestuário, pelo prazer do absurdo, passou" 22 .

Dando continuidade à análise dessa temática, Na edição de número 699, lançada em novembro de 1921, o principal chargista da Careta, J. Carlos, publicou a ilustração abaixo:

\footnotetext{
${ }^{21}$ SEVCENKO, Nicolau. Literatura como missão: tensões sociais e criação cultural na Primeira República. São Paulo: Brasiliense, 1999, p. 96-97.

${ }^{22}$ CIDADE, João da. "Um sorriso para todas". Careta, Rio de Janeiro, ano XII, n. 601, dez. 1919, p. 11. 


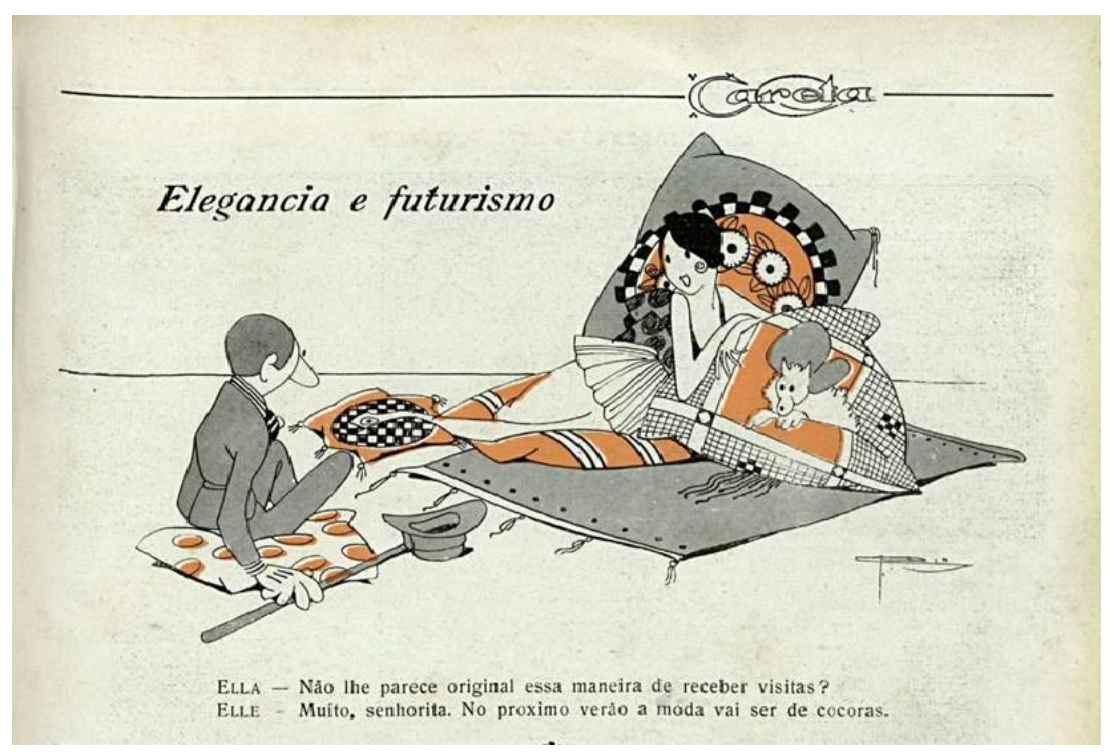

Fig. 1 - Charge de J. Carlos publicada na Careta, n. 699, nov. $1921^{23}$.

A exuberante melindrosa, deitada em um tapete cinza, cercada de almofadas com estampas extravagantes, em vestes e postura corporal ousadas recebe um mirrado cavalheiro que está usando o tradicional vestuário masculino formado pelo terno, gravata, chapéu e bengala. Ambos estão sentados de frente para o outro. Ao ser questionado, pela moça, sobre o que estava achando daquela nada convencional maneira de sua visita ser recebida, o atônito homem responde a pergunta com uma desconcertante ironia, que potencializa a sensação de desconforto transmitida pela ilustração traçada por J. Carlos. Conforme se pode deduzir, a imagem endossa a ideia de que o vanguardismo e a contestação de costumes tradicionais, de acordo com a visão de vários colaboradores do periódico aqui estudado, nem sempre foram associados ao conceito de progresso ou, de forma geral, concebidos como tendências culturais proveitosas.

Em abril de 1922, um jornalista que assinou a crônica "Futurismo...", com a alcunha de João Chrispim, teceu algumas espirituosas considerações sobre o tema que merecem aqui uma maior atenção. $\mathrm{Na}$ ocasião, Chrispim discorre sobre o assunto, inicialmente, narrando as inciativas intelectuais $e$ os singulares trejeitos de um futurista chamado Sérgio:

O meu amigo Sérgio, crítico literário, hóspede de casa de pensão, estudante de direito, escritor de pró-labores a $20 \$ 000$ e, mais do que tudo isso, um futurista de imensa imaginação, vai publicar uma revista intitulada Vida literária. A notícia é positivamente agradável. Espera-se todo o sucesso...

${ }^{23}$ CARLOS, J. (José Carlos de Brito e Cunha). "Elegância e futurismo". Careta, Rio de Janeiro, ano XIV, n. 699, nov. 1921. 
Mas, Sergio, que usa um pedaço de monóculo no olho direito, sempre que me topa ali pelas esquinas, atravessa-me o caminho com um gesto alto e discreto, ajeita no olho o seu brunido cristal e entra a definir copiosamente o que seja o futurismo.

Eu, na minha modéstia, não sei nem mesmo duma qualificação para essa inovação moderna dos artistas e dos pensadores. Será o futurismo uma filosofia, ou uma simples expressão de arte, ou apenas um rótulo capaz de especificar as doenças, as manias e os estados d'alma dos poetas? Quem sabe lá? Pergunta aí a qualquer um desses sonhadores, que é o futurismo. Nem eles sabem...

Entretanto, eu vou cometer aqui uma imperdoável irreverencia para com esses moços que ajeitam os seus monóculos parados ás esquinas, o braço em arco, pálidos, faces encovadas, a mão branca e longa nos acenando gestos nervosos. - com a afirmação que, a respeito do futurismo, me fez o meu vendeiro, o Sr. Manoel, legítimo português do Minho, homem de tamancos, proprietário abastado e, no fundo, muito bom coração, muito boa pessoinha... ${ }^{24}$ [grifos do autor]

O texto é encerrado após o diálogo entre o narrador e o prosaico comerciante português em torno do significado do conceito criado por Marinetti. Na ocasião, a associação feita pelo vendedor entre futurismo e práticas libidinosas provoca o riso desvairado de Chrispim, que afirma: "desse tal de futurismo ainda havia de nos sair uma grossa revelação" 25 . O pesquisador Felipe Botelho Corrêa fez um amplo estudo sobre a até então desconhecida produção literária do escritor carioca em periódicos como a Careta. Essas fontes foram publicadas ao longo da segunda década do século $\mathrm{XX}$ e assinados por diversos pseudônimos usados pelo autor de Isaías Caminha. Na introdução da recente antologia com cerca de 164 textos inéditos de Lima Barreto, intitulada Sátiras e outras subversões, Corrêa afirma que João Chrispim foi um desses alter egos usados pelo autor carioca ao longo de sua colaboração com o periódico aqui analisado ${ }^{26}$.

É pertinente pensar que temas essencialmente modernistas como a apologética da melancolia, o humor e a sátira política da época, o misticismo, o espírito antiacadêmico e o diálogo entre diferentes manifestações artísticas como a literatura, pintura, música e fotografia já eram frequentes entre os escritos de literatos cariocas consagrados como Afrânio Peixoto, Coelho Neto, João do Rio, Gonzaga Duque e Graça Aranha, bem como dos que não se enquadravam no arquétipo do intelectual

${ }^{24}$ CHRISPIM, João (Lima Barreto). "Futurismo". Careta, Rio de Janeiro, ano XV, n. 720, abr. 1922, p. 30.

${ }^{25}$ CHRISPIM, "Futurismo", p. 30.

${ }^{26}$ CORREA, Felipe Botelho. "Introdução". In: BARRETO, Lima. Sátiras e outras subversões. São Paulo: Companhia das Letras, 2016, p. 31. 
triunfante, de alto prestígio, tal qual um Lima Barreto. Em uma carta para Mário de Andrade, escrita provavelmente em 20 de julho de 1922, o historiador Sérgio Buarque de Holanda relata que o terceiro número do periódico Klaxon, mantido pelos modernistas paulistas, foi bem elogiado pela imprensa carioca em colunas assinadas por jornalistas e escritores de distintos matizes como Gomes Leite, Oswaldo Orico, Cláudio Ganns e Enéas Ferraz que atuavam em impressos tais quais A Noite, Imparcial, O Paiz e o Rio-Jornal. Ao viajar até a então capital da República com o intuito de divulgar as ideias de seu grupo entre os escritores cariocas, Sérgio escreveu ainda, na citada missiva, o seguinte trecho: "Além disso, dei um número ao Lima Barreto a fim que escrevesse qualquer coisa na Careta, elogio ou ataque, de modo a despertar atenção" 27.

Pouco tempo depois Lima publicou uma nova crônica intitulada "O futurismo", devidamente assinada, na Careta. Conforme se pode perceber, não apenas os títulos dos textos são semelhantes. Há também uma analogia muito forte em termos de estilo literário entre esses escritos:

São Paulo tem a virtude de descobrir o mel de pão em ninho de coruja. De quando em quando, ele nos manda umas novidades velhas de quarenta anos. Agora, por intermédio do meu simpático amigo Sérgio Buarque de Holanda, quer nos impingir como descoberta dele, S. Paulo, o tal de 'Futurismo'. Ora, nós já sabíamos perfeitamente da existência de semelhante maluquice, inventada por um senhor Marinetti, que fez representar em Paris, num teatro de arrabalde, uma peça-Le Roi Bombance - cuja única virtude era mostrar que "il Marinetti" tinha lido demais Rabelais.

[...]

Recebi, e agradeço uma revista de São Paulo que se intitula Klaxon. Em começo, pensei que se tratasse de uma revista de propaganda de alguma marca de automóveis americanos. Não havia para tal motivos de dúvidas, porque um nome tão estrambótico não podia ser senão inventado por mercadores americanos, para vender o seu produto.

[...]

Disse cá comigo: esses moços tão estimáveis pensam mesmo que nós não sabíamos disso de futurismo? Ha vinte anos, ou mais, que se fala nisto e não há quem leia a mais ordinária revista francesa ou o pasquim mais ordinário da Itália que não conheça as cabotinagens do 'il Marinetti'.

A originalidade desse senhor consiste em negar quando todos dizem sim; em avançar absurdos que ferem, não só o senso comum, mas tudo o que é base e força da humanidade. ${ }^{28}$

${ }^{27}$ Cf. ANDRADE, Mário de \& HOLANDA, Sérgio Buarque de. Correspondência. São Paulo: Companhia das Letras; Instituto de Estudos Brasileiros; EDUSP, 2012, p. 50.

${ }^{28}$ BARRETO, Lima. "O Futurismo". Careta, ano XV, n. 735, Rio de Janeiro, jul. 1922, p. 10. 
O Lima Barreto que o então bastante jovem historiador paulista encontrou já estava bastante debilitado fisicamente e psicologicamente devido ao consumo excessivo do álcool - naquele mesmo ano, o escritor veio a falecer. Entretanto, os textos ferinos e engajados feitos por esse literato carioca contra os parnasianos, a política oficial e a alta cúpula da Academia Brasileira de Letras não passaram despercebidos pelos modernistas paulistas. Ao tornar públicas suas impressões sobre a Klaxon, Lima Barreto fez jus a já consolidada fama de severo polemista e demonstrou seu nítido repúdio em face das diretrizes políticas e estéticas futuristas a nível local e internacional.

A Klaxon teve uma breve existência que durou nove edições. O terceiro número, lançado em 15 de junho de 1922, entregue por Sérgio para Lima Barreto possuía poemas, crônicas e textos de autores oriundos de distintas regiões do Brasil como Antônio Ferro, Sérgio Milliet, Manoel Bandeira, Ronald de Carvalho, Guilherme de Almeida, Menotti del Pichia, Ribeiro Couto, Mario de Andrade, Motta Filho e Ribeiro Cavalcanti. Os escritos em francês do paulista Sérgio Milliet e do pernambucano Manoel Bandeira são evidências do caráter aristocrático da Klaxon, bem como sugerem que a francofilia que dominou o cenário intelectual da bela época não foi, de forma alguma, submetida a uma ruptura radical pelo modernismo paulista ${ }^{29}$.

É muito provável que o deboche direcionado por Lima Barreto para os futuristas paulistas tenha acarretado a sobrevida de certo ressentimento mesmo muitos anos depois da ocasião de seu encontro com o crítico e historiador Sérgio Buarque. Na ocasião da editoração e publicação das obras completas do autor carioca pela Editora Brasiliense, ao prefaciar o romance Clara dos Anjos, em 1956, Sérgio fez o seguinte julgamento crítico em torno da qualidade literária dos textos barretianos:

A obra deste escritor é, em grande parte, uma confissão mal escondida, confissão de amarguras íntimas, de ressentimentos, de malogros pessoais que nos seus melhores momentos ele soube transfigurar em arte. [...]

[...]

A propósito lembra-me nitidamente, dentre as poucas $e$ confusas recordações que me ficaram de Lima Barreto, quando o conheci pessoalmente no último ano de sua vida, este comentário bem expressivo, apesar de toda reserva irônica que reserva:

- Poeta era o Verlaine. Bebia como uma cabra...

Outra lembrança que conservo vivamente é a de seu desapreço, em mais de uma ocasião manifestado, pela obra de Machado de Assis. ${ }^{30}$

Não cabe aqui esmiuçar as razões que tornaram a aproximação entre um dos principais modernistas cariocas e os futuristas paulistas um episódio turbulento da

${ }^{29}$ Cf. KLAXON, São Paulo, n. 3, julho de 1922, p. 6.

${ }^{30}$ HOLANDA, Sérgio Buarque de. "Prefácio". In: BARRETO, Lima. Clara dos Anjos. São Paulo: Brasiliense, 1956, p. 9-11. 
história intelectual brasileira. Até mesmo a insistente comparação entre o valor estético das obras barretianas e a ficção de Machado de Assis pela qual adentra o Sérgio Buarque maduro, no seu "Prefácio" para Clara dos Anjos, é um exercício interpretativo que possui várias limitações. É interessante perceber, no entanto, que os ideais futuristas de luta pela pátria e suas grandezas, o tecnicismo, elitismo e o apreço por pelejas belicosas internacionais, para um autor simpático ao ideal de solidariedade humana e pacifista como Lima Barreto, não pareceram diretrizes artísticas tão vanguardistas assim.

Nesse sentido, conforme já percebeu o crítico literário Antonio Arnoni Prado ${ }^{31}$, o heterogêneo grupo de futuristas que engendraram a Semana de 1922 silenciaram, deliberadamente, os debates anteriores e fora de São Paulo que já vinham acontecendo na imprensa sobre a temática há mais de uma década, bem como parcela significativa da literatura engajada com denúncias sociais - sobretudo, de cunho anarquista - extremamente lúcidas e modernistas, no sentido amplo do conceito.

\section{$\operatorname{soc} 2$}

\section{RESUMO}

O futurismo, enquanto vanguarda estética, está estreitamente entrelaçado com o conceito de modernismo. $\mathrm{O}$ modernismo enquanto movimento literário foi bastante expressivo e abarcou manifestações políticas, teorias $e$ grupos sociais, ocorrendo em diferentes lugares $e$ momentos. Alguns manifestos lançados no começo do século XX eram feitos através de redes de intelectuais, que tinham em comum o gosto pela discussão de teorias e correntes estéticas. Essas ideias circulavam rapidamente em diferentes países. Modernismo e futurismo representam um novo olhar para a arte, bem como suas funções. Desse modo, o escopo deste artigo é analisar os debates e polêmicas literárias em torno da temática do futurismo na imprensa carioca, em um contexto anterior ao da Semana de Arte Moderna em 1922.

Palavras Chave: Futurismo; História das Ideias; Imprensa Carioca.

\begin{abstract}
Futurism, as an aesthetic avant-garde, is quite interconnected with the concept of Modernism. The modernism, as a literary movement, was quite expressive and encompassed political manifestations, theories and social groups, occurring in different places and times. Some manifests launched at the beginning of $20^{\text {th }}$ century were made through networks of intellectuals, who had in common the taste for the discussion of the thematic currents and theories. These ideas circulated rapidly in different countries. Modernism and Futurism represents a new look at Art as well as its functions. Thus, the scope of this article is to analyze the debates and literary controversies around the theme of Futurism in the Rio de Janeiro's magazine Careta, in a previous context to the Semana de Arte Moderna ("Modern Art Week") in 1922.
\end{abstract}

Keywords: Futurism; History of Ideas; Rio de Janeiro Press.

Artigo recebido em 21 jun. 2017.

Aprovado em 07 ago. 2017.

${ }^{31}$ PRADO, Antonio Arnoni. Itinerário de uma falsa vanguarda: os dissidentes, a semana de 22 e o Integralismo. São Paulo: Editora 34, 2010. 